\title{
Determination of Antioxidant Activity by Oxygen Radical Absorbance Capacity (ORAC-FL), Cellular Antioxidant Activity (CAA), Electrochemical and Microbiological Analyses of Silver Nanoparticles Using the Aqueous Leaf Extract of Solanum
} mammosum L.

\author{
Fernanda Pilaquinga $\mathbb{D}^{1,2}$ \\ Jeroni Morey ${ }^{2}$ \\ Lenys Fernandez' \\ Patricio Espinoza-Montero (D) \\ Mauricio Moncada-Basualto ${ }^{3}$ \\ Josue Pozo-Martinez ${ }^{3}$ \\ Claudio Olea-Azar ${ }^{3}$ \\ Rafael Bosch ${ }^{4}$ \\ Lorena Meneses' \\ Alexis Debut ${ }^{5}$ \\ María de las Nieves Piña ${ }^{2}$ \\ 'School of Chemical Sciences, Pontificia \\ Universidad Católica del Ecuador, Quito, \\ Ecuador; ${ }^{2}$ Department of Chemistry, \\ University of the Balearic Islands, Palma de \\ Mallorca, Spain; ${ }^{3}$ Department of Inorganic \\ and Analytical Chemistry, University of \\ Chile, Santiago, Chile; ${ }^{4}$ Environmental \\ Microbiology, IMEDEA (CSIC-UIB), and \\ Microbiology, Department of Biology, \\ University of Balearic Islands, Palma de \\ Mallorca, Spain; ${ }^{5}$ Centro de Nanociencia \\ y Nanotecnología, Universidad de las \\ Fuerzas Armadas ESPE, Sangolquí, Ecuador
}

Correspondence: Fernanda Pilaquinga School of Chemical Sciences, Pontificia Universidad Católica del Ecuador, Quito, Ecuador

Tel +59327427510

Email mfpilaquingaf@puce.edu.ec
Purpose: The importance of studying polyphenolic compounds as natural antioxidants has encouraged the search for new methods of analysis that are quick and simple. The synthesis of silver nanoparticles (AgNPs) using plant extracts has been presented as an alternative to determine the total polyphenolic content and its antioxidant activity.

Methods: In this study, aqueous leaf extract of Solanum mammosum, a species of plant endemic to South America, was used to produce AgNPs. The technique of oxygen radical absorption capacity using fluorescein (ORAC-FL) was used to measure antioxidant activity. The oxidation of the $2^{\prime}, 7^{\prime}$-dichlorodihydrofluorescein diacetate $\left(\mathrm{DCFH}_{2}\right.$-DA) as fluorescent probe was used to measure cellular antioxidant activity (CAA). Electrochemical behavior was also examined using differential pulse voltammetry (DPV) and cyclic voltammetry (CV). Total polyphenolic content (TPH) was analyzed using the Folin-Ciocalteu method, and the major polyphenolic compound was analyzed by high performance liquid chromatography with diode array detector (HPLC/DAD). Finally, a microbial analysis was conducted using Escherichia coli and Bacillus sp.

Results: The average size of nanoparticles was $5.2 \pm 2.3 \mathrm{~nm}$ measured by high-resolution transmission electron microscopy (HR-TEM). The antioxidant activity measured by ORAC-FL in the extract and nanoparticles were $3944 \pm 112$ and $637.5 \pm 14.8 \mu \mathrm{M} \mathrm{ET} / \mathrm{g}$ of sample, respectively. Cellular antioxidant activity was $14.7 \pm 0.2$ for the aqueous extract and $12.5 \pm 0.2$ for the nanoparticles. The electrochemical index (EI) was $402 \mu \mathrm{A} / \mathrm{V}$ for the extract and $324 \mu \mathrm{A} / \mathrm{V}$ for the nanoparticles. Total polyphenolic content was $826.6 \pm 20.9$ and $139.7 \pm 20.9 \mathrm{mg}$ EGA/100 $\mathrm{g}$ of sample. Gallic acid was the main polyphenolic compound present in the leaf extract. Microbiological analysis revealed that although leaf extract was not toxic for Escherichia coli and Bacillus sp., minor toxic activity for AgNPs was detected for both strains.

Conclusion: It is concluded that the aqueous extract of the leaves of S. mammosum contains nontoxic antioxidant compounds capable of producing AgNPs. The methods using AgNPs can be used as a fast analytical tool to monitor the presence of water-soluble polyphenolic compounds from plant origin. Analysis and detection of new antioxidants from plant extracts may be potentially applicable in biomedicine.

Keywords: silver nanoparticles, Solanum mammosum, antioxidant activity, ORAC, voltammetry 


\section{Introduction}

The therapeutic importance of antioxidants and the side effects reported from synthetic compounds has motivated the search for alternative sources. ${ }^{1-3}$ In this interesting analysis, plants and their biodiversity constitute an inexhaustible source of exploration. ${ }^{4}$ Silver nanoparticles (AgNPs) can be prepared with plant extracts through a chemical reduction process involving polyphenolic compounds, ${ }^{5,6}$ organic acids, ${ }^{7}$ and reducing sugars, ${ }^{8}$ among others. ${ }^{3}$ Plant extracts stabilize the size and shape of nanoparticles. ${ }^{9,10}$ Further, they provide them with additional properties depending on their nature. $^{11}$ In addition to their antimicrobial attributes, ${ }^{12}$ AgNPs have optical properties that make them ideal tools for the detection of chemical reactions; ${ }^{13}$ they display the surface plasmon resonance (SPR) phenomenon, which consists of a collective oscillation of conduction electrons at the surface. $^{14,15}$

According to this principle, analyzing their formation is quite simple, so they can be used as an analytical method with species like polyphenolic compounds, especially considering how complex it is to study them in plant matrices. ${ }^{16}$ As antioxidants, polyphenolic compounds have the ability to remove free radicals $^{17}$ and inhibit prooxidant enzymes. ${ }^{18}$ Oxidative stress is an imbalance between the generation and elimination of reactive species or free radicals, which both have a missing electron. ${ }^{19}$ These radicals can be caused by cellular metabolism, a clear example being reactive oxygen species (ROS) and reactive nitrogen species (RNS), among them the superoxide anion, hydroxyl radical, hydrogen peroxide, and nitric oxide. ${ }^{20,21}$ ROS and RNS cause severe cell damage associated with a wide list of diseases such as metabolic syndrome, ${ }^{22}$ cancer, ${ }^{23}$ Alzheimer's disease, ${ }^{24}$ and cardiovascular problems. $^{25}$ Antioxidant activity limits the generation of free radicals $^{26}$ and can be measured by chemical, ${ }^{27}$ electrochemical, ${ }^{28}$ or cellular methods. ${ }^{29}$ Its effectiveness is evaluated with physiologically active antioxidants such as glutathione, ${ }^{30} \alpha$-tocopherol, ${ }^{31}$ ergothioneine, ${ }^{32}$ and synthetics such as Trolox, ${ }^{33}$ BHT, $^{34}$ and BHA. ${ }^{35}$

Most studies that measure antioxidant activity using silver nanoparticles are based on methods such as DPPH (2,2-diphenyl-1-picryl-hydrazyl-hydrate), ABTS (2,2'azino-bis [3- ethylbenzothiazoline-6-sulfonic acid]), and FRAP (ferric reducing ability of plasma), among others. $^{36,37}$ The technique of oxygen radical absorption capacity using fluorescein (ORAC-FL) ${ }^{38,39}$ has been applied very infrequently to analyze the behavior of different nanoparticles, especially using plant extracts, ${ }^{28,40-43}$ as have electrochemical methods such as differential pulse voltammetry (DPV) and cyclic voltammetry (CV). ${ }^{36,37}$ However, all these methods do not accurately reflect the antioxidant capacity at the cellular level, since physiological conditions such as $\mathrm{pH}$, temperature, bioavailability and metabolism are not taken into account, so the use of in vitro models would allow a better approach for the determination of the antioxidant capacity.

Species of the genus Solanum are rich in polyphenolic compounds. Solanum mammosum L. (Sm) is a herbaceous species belonging to the Solanaceae family. ${ }^{38,39}$ In South America, it is commonly known as "teta de vaca" ("cow's udder") for the characteristic shape of its fruit. ${ }^{40}$ The plant's stem measures between 1 and $1.5 \mathrm{~m}$ in height, is fuzzy from the presence of glandular hairs, and has yellowish, smooth or curved thorns that are $10-15 \mathrm{~mm}$ wide at the base and approximately $22 \mathrm{~mm}$ long. Its leaves are oval-shaped with five to seven shallow lobes and irregular toothed margins; they are relatively thin and have an alternating arrangement and a truncated base. S. mammosum contains catechins, tannins, alkaloids, simple phenols, flavanones, flavonoids, cyanogenic heterosides, saponins, and triterpenes. ${ }^{39,40}$ It is known for its antioxidant, $^{41}$ anticancer, ${ }^{42,43}$ antimalarial, ${ }^{44}$ molluscicidal activity, $^{45-48}$ and its toxic effects on pests ${ }^{49-51}$ and vectors. ${ }^{52}$ In vitro studies have also been conducted to structurally biotransform compounds with therapeutic properties from cell suspension cultures. ${ }^{53-58}$

In the current study, AgNps were used as sensors to determine the antioxidant activity of the aqueous extract of $S$. mammosum by ORAC-FL, cellular antioxidant activity by CAA, cyclic voltammetry (CV), and differential pulse voltammetry (DPV) as electrochemical analyses. The extract's total polyphenolic content and phenolic profile were determined through high-performance liquid chromatography with diode array detector (HPLC/DAD). In addition, microbiological analysis was development to test the toxicity of the plant extract used and the nanoparticles obtained.

\section{Materials and Methods}

\section{Preparation of Aqueous Extract from}

\section{S. mammosum Leaves}

The protocol suggested by Pilaquinga et $\mathrm{al}^{59}$ was used. Fresh $S$. mammosum leaves were collected in the Marianitas precinct (located at $0^{\circ} 05^{\prime} 46.3^{\prime \prime} \mathrm{N}, 7^{\circ} 07^{\prime} 33.5^{\prime \prime} \mathrm{O}$; altitude: $135 \mathrm{~m}$. a.s.1.). The collection was carried out with a Wildlife Management Patent No66-2019-ICFAU-FLO DPAI/MAE from the Herbarium ECAA-PUCESI and authorization for 
Scientific Research No 006-2019-IC-FAU-FLO-DPAI/MAE from the Ministry of the Environment of Ecuador. A botanical voucher was previously deposited for reference at the Center for Research on Health in Latin America $(\mathrm{CISeAL}){ }^{59}$ The samples were washed with distilled water to remove impurities and dried in the shade at room temperature $\left(20^{\circ} \mathrm{C}\right)$ for one week. The sample was ground in a microfine grinder MF 10 (IKA, Königswinter, Germany). To prepare the aqueous extract, $1 \mathrm{~g}$ of sample was placed in $20 \mathrm{~mL}$ of distilled water and constantly stirred and heated on a heating plate (Glassco, Haryana, India) at room temperature for $1 \mathrm{~h}$.

\section{Microwave-Assisted Synthesis of AgNPs-Sm}

To synthesize the AgNPs-Sm in colloid dispersion, the method suggested by Joseph and Mathew ${ }^{60}$ was followed, with slight modifications. The parameters of the precursor concentration, amount of aqueous extract of $S$. mammosum leaves, $\mathrm{pH}$, time, and power were set. For the optimized method, $20 \mathrm{~mL}$ of $\mathrm{AgNO}_{3} 99.9 \%$ purity (Merck 99.9\%, Darmstadt, Germany), $1 \mathrm{mmol} \mathrm{L}^{-1}$ and $1 \mathrm{~mL}$ of the aqueous extract were used. The $\mathrm{pH}$ was adjusted to 8 with $\mathrm{NaOH} 1 \%$ (Merck 99.9\%, Darmstadt, Germany), time 90 s, and power $800 \mathrm{~W}$ using a microwave MWI 28BL (Indurama, Cuenca, Ecuador). To obtain solid nanoparticles was necessary $2 \mathrm{~mL}$ of the leaf extract of $S$. mammosum, $20 \mathrm{~mL}$ of $\mathrm{AgNO}_{3} 50$ $\mathrm{mM}, \mathrm{pH} 9,40^{\circ} \mathrm{C}$ and stirring agitation during 30 minutes on a heating plate (Velp Scientifica, Usmate Velate, Italy). The solid residue was centrifuged for 10 minutes to $6000 \mathrm{rpm}$ and decanted. Finally, the decanting was washed with distilled water and dried under infrared light at $30 \mathrm{~cm}$ of distance during 3 hours.

\section{Characterization of AgNPs-Sm}

To monitor the formation of the AgNPs-Sm, a Cary 60 double-beam UV-Visible spectrophotometer (Agilent Technologies, Santa Clara, CA, USA) was used. To determine the size of nanoparticles, a Tecnai $G^{2}$ F20 highresolution transmission electron microscope (HR-TEM) (FEI Tecnai, Hillsboro, OR, USA) was used. The nanoparticles' hydrodynamic radius was measured with a dynamic light scattering meter (DLS) using an LB-550 nanoparticle size analyzer (HORIBA, Kyoto, Japan). X-ray diffraction (XRD) patterns were collected with a diffractometer (PANalytical EMPYREAN, Almelo, The Netherlands) with a Bragg-Brentano $(\Theta-2 \Theta)$ configuration set to $40 \mathrm{kV}, 45 \mathrm{~mA}$, and monochrome X-rays with a $\mathrm{Cu}$ $\mathrm{K}-\alpha$ wavelength $(\lambda=1.541 \AA)$; a Ni filter was used. The FTIR-ATR spectra were obtained with a spectrophotometer (Perkin Elmer, Spectrum BX FTIR, Waltham, MA, USA) with ATR coupling (resolution from $4 \mathrm{~cm}^{-1}$ to $4000-400 \mathrm{~cm}^{-1}$ and 10 scans per sample with intervals of $2 \mathrm{~cm}^{-1}$ ).

\section{Total Antioxidant Activity by Oxygen Radical Absorbance Capacity (ORAC-FL)}

Antioxidant capacity was determined using the ORACfluorescence methodology (ORAC-FL). ${ }^{61-65}$ The analyses were performed using a 96-well white polystyrene plate reader (EnSpire multimode PerkinElmer, Waltham, MA, USA). The reaction was carried out in phosphate buffer of $75 \mathrm{mM}$ (pH 7.4). The sample was homogenized and incubated at $37{ }^{\circ} \mathrm{C}$ for $5 \mathrm{~min}$ with $150 \mu \mathrm{L}$ of fluorescein solution ( $40 \mathrm{nM}$, final concentration). Then, $25 \mu \mathrm{L}$ of $2,2^{\prime}-$ azobis(2-methylpropionamidine) dihydrochloride (SigmaAldrich 97\%, St Louis, MO, USA) $18 \mathrm{mmol} \mathrm{L}^{-1}$ was added; the fluorescence was registered with an excitation wavelength of 485/20 nm and an emission filter of 528/20 $\mathrm{nm}$ at a constant temperature of $37{ }^{\circ} \mathrm{C}$ in a Synergy HT multi-detection microplate reader (Bio-Tek Instruments, Winooski, VT, USA) every minute for $2 \mathrm{~h}$. The results were expressed as $\mu \mathrm{mol} \mathrm{L}{ }^{-1}$ Trolox equivalent/g of sample. A Trolox calibration curve was used with a concentration range between 3 and $20 \mu \mathrm{mol} \mathrm{L}^{-1}$.

\section{Cellular Antioxidant Activity (CAA)}

Cellular antioxidant activity (CAA) was evaluated in VERO cell line culture (European Collection of Cell Cultures, ECACC 84113001) using 2',7'-dichlorodihydrofluorescein diacetate $\left(\mathrm{DCFH}_{2}-\mathrm{DA}\right)$ as a fluorescent probe. ${ }^{62}$ The cells were plated in sterile, white, polystyrene, flat-bottom 96-well microplates (Nunc, Denmark) at a concentration of 50,000 cells per well and incubated for $24 \mathrm{~h}$ at $37^{\circ} \mathrm{C}$ and $5 \% \mathrm{CO}_{2}$ in RPMI 1640 culture medium. The cells were washed with $150 \mathrm{~mL}$ of phosphate buffered saline (PBS) $\mathrm{pH} 7.4$ and incubated for $1 \mathrm{~h}$ with $100 \mu \mathrm{L}$ of RPMI 1640 containing 20 $\mu \mathrm{M}$. The aqueous extract and AgNPs-Sm were added in a final concentration of $21 \mathrm{mg} \mathrm{mL}^{-1}$. After $2 \mathrm{~h}$ of incubation, the medium was discarded, and the cells were gently washed twice with $100 \mu \mathrm{L}$ of PBS. Then, they were incubated with 2,2'-Azobis(2-methylpropionamidine) dihydrochloride (AAPH) (Sigma-Aldrich 97\%, St Louis, MO, USA) at a final concentration of $600 \mu \mathrm{M}$ in PBS. Fluorescence was 
measured immediately after addition in a spectrofluorometer (Bio-Tek Instruments, Winooski, VT, USA) in 96-well plates at $37{ }^{\circ} \mathrm{C}$ using an excitation of $485 \mathrm{~nm}$ and an emission of $538 \mathrm{~nm}$. The evaluation was carried out every min for $1 \mathrm{hr}$, and the CAA values were calculated with Equation (1):

$$
\% C A A=100-\left(\frac{\Delta F_{A H}}{\Delta F} * 100\right)
$$

where $\mathrm{F}$ is the fluorescence intensity in the presence of free radicals without the extract, and $\mathrm{F}_{\mathrm{AH}}$ is the fluorescence intensity in the presence of free radicals, extract, and AgNPs$\mathrm{Sm}$. All measurements were done in the same period.

\section{Antioxidant Activity by Differential Pulse Voltammetry (DPV) and Cyclic Voltammetry (CV)}

For the analysis, the protocol suggested by Pilaquinga et al was followed. ${ }^{66}$ A CH-Instruments potentiostat, model 700D (Tennison Hill Drive Austin, TX, USA) coupled to a conventional $15 \mathrm{~mL}$ three-electrode reaction cell was used. Glassy carbon (GC) was used as a working electrode, $\mathrm{Ag} / \mathrm{AgCl}$ as a reference electrode, and a platinum wire $(0.5 \mathrm{~cm}$ in diameter and $3 \mathrm{~cm}$ long) as a counter electrode. The glassy carbon electrode was polished with alumina paste $\left(\mathrm{Al}_{2} \mathrm{O}_{3}, 0.25 \mu \mathrm{m}\right.$, Struers, Copenhagen, Denmark) to obtain a mirror-like surface $\left(0.066 \mathrm{~cm}^{2}\right)$, followed by sonication for $5 \mathrm{~min}$. Differential pulse voltammetry and cyclic voltammetry were performed in an electrolyte solution of sodium acetate $0.1 \mathrm{~mol} \mathrm{~L}^{-1}$, with a range of $-1.2 \mathrm{~V}$ to $1.3 \mathrm{~V}$.

\section{Total Polyphenolic Content (TPH)}

Total polyphenolic content (TPH) was determined using the Folin-Ciocalteu spectrophotometric method. ${ }^{67}$ Two hundred $\mu \mathrm{L}$ of Folin-Ciocalteu reagent (Merck 99.99\%, Darmstadt, Germany) was added to $15 \mu \mathrm{L}$ of extract/ AgNPs; the mixture was homogenized and left to incubate for $5 \mathrm{~min}$. Then, $40 \mu \mathrm{L}$ of $\mathrm{Na}_{2} \mathrm{CO}_{3} 20 \%(\mathrm{~m} / \mathrm{v})$ and $45 \mu \mathrm{L}$ of distilled water were added; the reaction mixture was homogenized and incubated for $30 \mathrm{~min}$ at $37{ }^{\circ} \mathrm{C}$. Afterward, absorbance at $760 \mathrm{~nm}$ was recorded with a Synergy HT microplate reader (Bio-Tek Instruments, Winooski, VT, USA).

\section{Phenolic Profile Determination}

The polyphenolic profile of the $S$. mammosum leaf extract was determined by high-performance liquid chromatography (HPLC) Series 1260 Infinity II (Agilent Technologies, Santa Clara, CA, USA) coupled to a diode array detector (DAD) (Santa Clara, CA, USA). A Chromolith C18 endcapped column $(150 \times 4.60 \mathrm{~mm}$, $5.0 \mu \mathrm{m}$ ) (Merck 99.99\%, Darmstadt, Germany) was used for identification. The sample injection volume was $20 \mu \mathrm{L}$, and the column temperature was set to ambient conditions. The mobile phase composition corresponded to phase A-acetic acid $2 \%$ in water and phase B-acetonitrile, with a gradient elution of $92 \%$ A decreasing $5 \%$ every 5 min at a constant flow rate of $500 \mu \mathrm{L} \mathrm{min}{ }^{-1}$. OpenLab ChemStation analysis software, version A 01.03 , was used for system control and data acquisition and processing.

\section{Microbiological Analysis}

Two isolates, Escherichia coli CECT 101 and Bacillus sp. CECT 40, both obtained from the Spanish Type Culture Collection (CECT, Valencia, Spain), were used. Minimum inhibitory concentration (MIC) analysis and agar dilution susceptibility tests were conducted as per the standard CLSI methods. ${ }^{68}$ For the agar dilution tests, three distinct quantities $(100,10$, and 1 micrograms) of each analyzed extract, nanoparticle, and compound were placed on different $6 \mathrm{~mm}$ Whatman ${ }^{\circledR}$ Antibiotic Assay Discs (Merck Life Science, Madrid, Spain). For the MIC analysis, a starting solution of $512 \mathrm{mg} / \mathrm{L}$ for each analyzed extract, nanoparticle, and compound was prepared.

\section{Statistical Analysis}

For the conditioning of microwave-assisted AgNPs-Sm synthesis, a $3 \mathrm{~K}$ factorial design was utilized. Analyses of antioxidant activity with ORAC-FL, CV, DPV, and total polyphenolic content were performed in triplicate. To analyze the results, a Student's $t$-test with a $95 \%$ confidence interval was used. Data were expressed as mean \pm standard deviation (SD). MIC experiments were performed in triplicates. Origin Pro 8.5 SR2 (Origin Lab Corporation, Washington, USA) was used for data analysis.

\section{Results and Discussion \\ Characterization of AgNPs-Sm}

The formation of AgNPs-Sm monitored by UV-Vis spectrophotometry is shown in Figure 1. The spectra absorption obtained with the optimized synthesis parameters such as potency, time, $\mathrm{pH}$, precursor and $S$. mammosum extract volume are indicated from $1 \mathrm{~A}$ to $1 \mathrm{E}$ respectively. According to the nanoparticle size estimate proposed by 
A

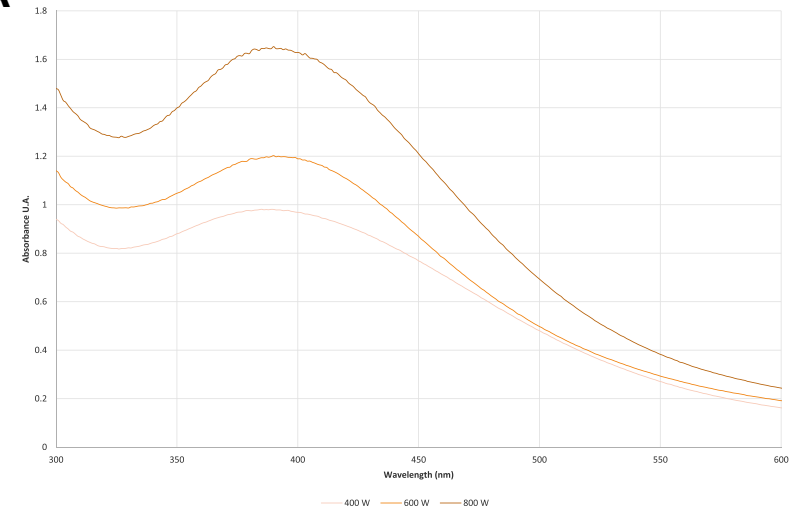

C

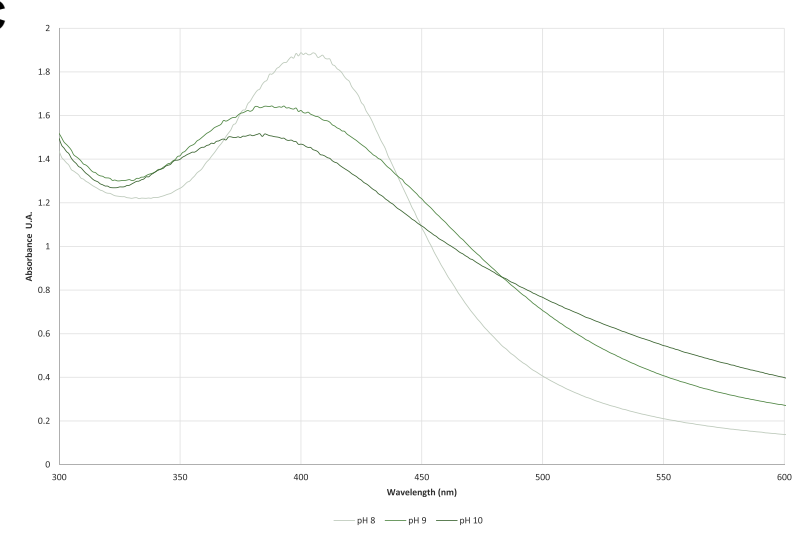

B

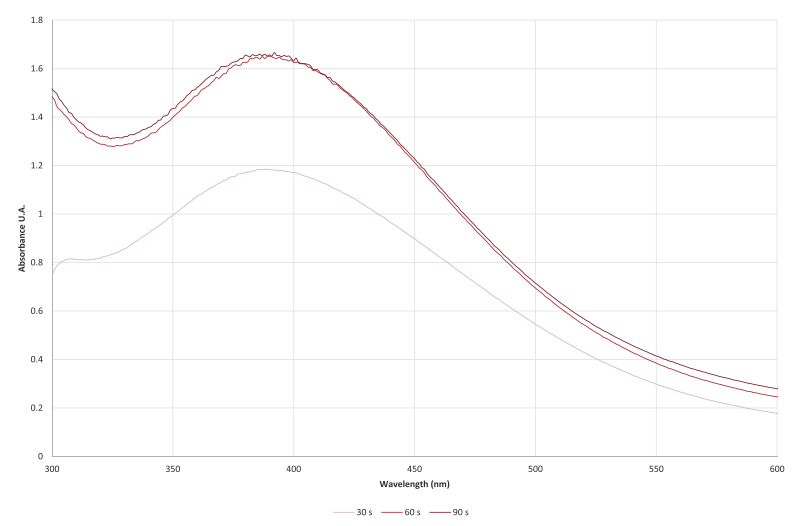

D

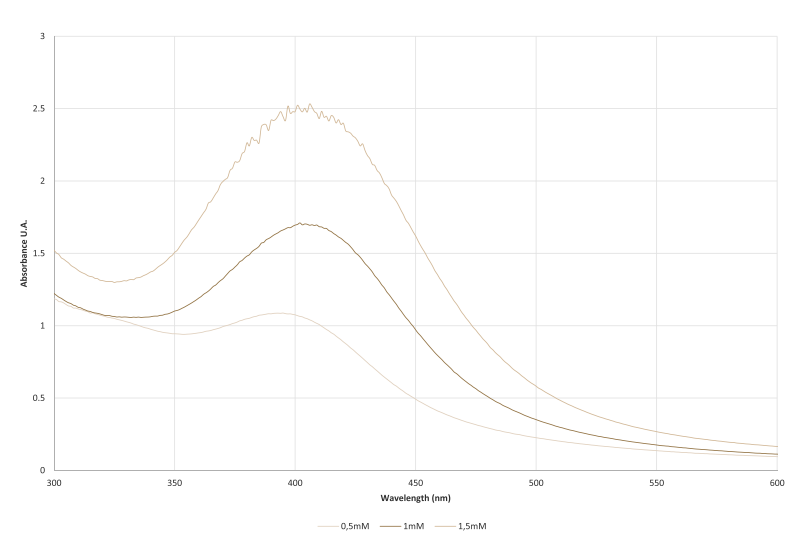

\section{E}

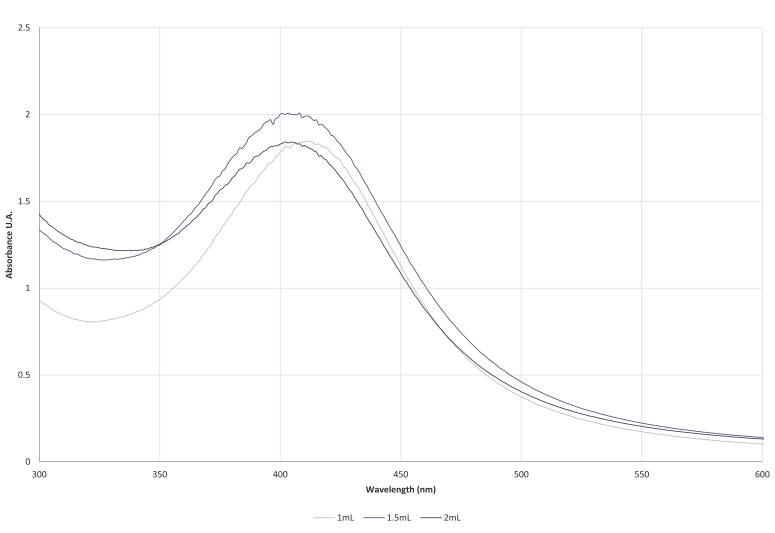

Figure I UV-Vis spectra of the AgNps optimization. (A) potency, (B) time, (C) pH, (D) precursor and (E) S. mammosum extract volume.

Pradeep, ${ }^{69}$ the surface plasmon suggests an approximate value of 30 to $50 \mathrm{~nm}$ with the organic coating. The actual size measured by HR-TEM was $5.2 \pm 2.3 \mathrm{~nm}$ as shown in Figure $2 \mathrm{~A}$ and the particle size histogram in Figure $2 \mathrm{~B}$. The morphology of the particles is quasi-spherical and polydispersed, as clearly observed. The d-spacing between the planes is calculated to be $0.25 \mathrm{~nm}$, which closely corresponds to the spacing between the (111) Ag (0.236 $\mathrm{nm})$ of the XRD pattern. Furthermore, some particles displayed multiple-twinned crystalline planes, indicating that they consist of several differentially oriented crystals, see Figure 2C. The selected area electron diffraction (SAED) pattern of the as-prepared silver nanoparticles is shown in Figure 2D and confirms the nanoparticles' crystalline nature and that the observed structure is silver. ${ }^{3,66}$ The size measured by the DLS was $22.1 \mathrm{~nm} \pm 2.3 \mathrm{~nm}$, which indicates that the organic coating's size is approximately $16.9 \mathrm{~nm},{ }^{70}$ which is consistent with the 

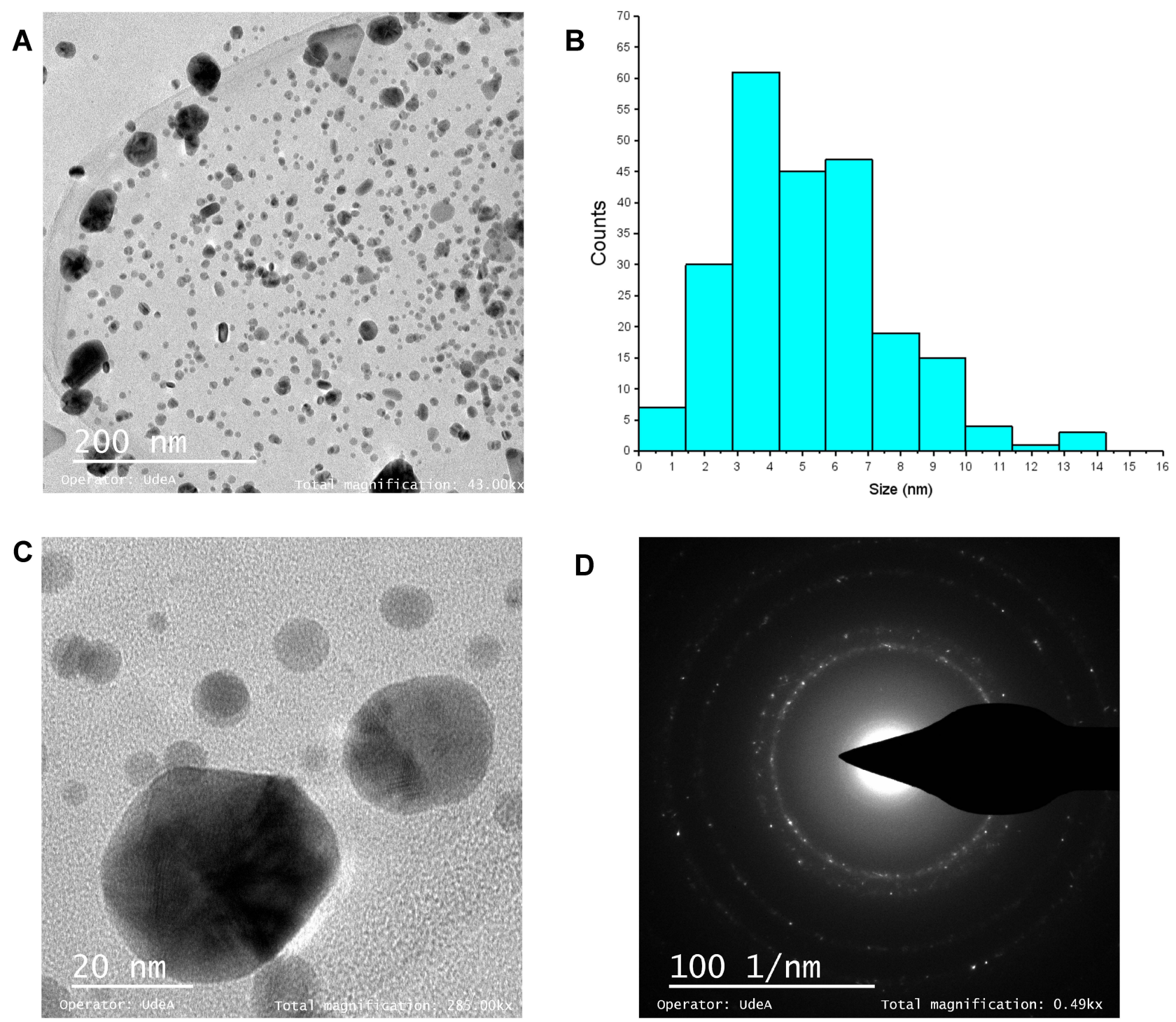

E

$\mathbf{F}$
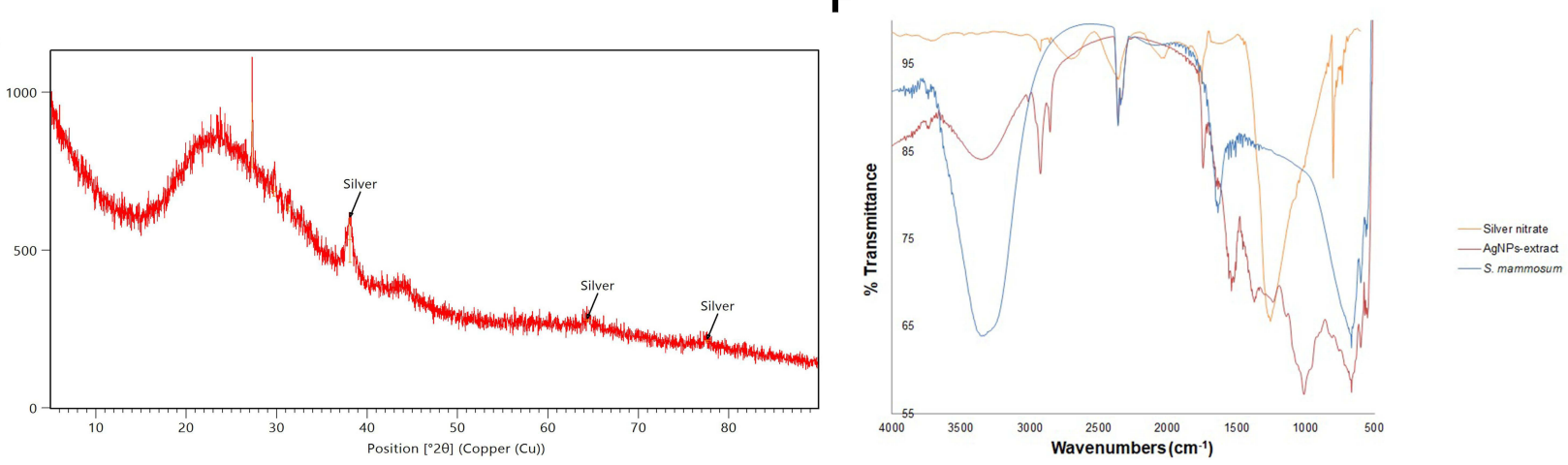

Figure 2 Characterization of AgNPs-Sm. (A) HR-TEM micrograph of AgNPs-Sm, (B) particle size histogram, (C) picture of a nanoparticle done with HR-TEM, (D) SAED of nanoparticle observed, (E) X-ray diffraction (XRD) pattern of AgNPs-Sm and (F) IR spectra of $\mathrm{AgNO}_{3}, \mathrm{AgNPs}_{\mathrm{g}} \mathrm{Sm}$ and S. mammosum extract.

nanoparticle size estimated by UV-Vis spectrophotometry. When comparing the size of the AgNPs-Sm obtained from the aqueous extract of $S$. mammosum fruit $(15.3 \pm 4.8 \mathrm{~nm})^{59}$ to those from other Solanum species such as S. melongena
L. $(24 \mathrm{~nm})^{71}$ and S. muricatum $(20-80 \mathrm{~nm})^{72}$ that used microwave-assisted synthesis, the observed size is significantly smaller. The analysis of the diffraction pattern (XRD) in Figure 2E shows the observed peaks at angles 
of $2 \theta$ for the silver nanoparticles are as follows: $32.8^{\circ}$, $38.0^{\circ}, 58.5^{\circ}$, and $65.4^{\circ}$ and correspond to the (111), (002), (122), and (220) reflection planes of a silver oxide cubic lattice referenced by ICDD 98-028-1041. The space group is $\mathrm{Pn}-3 \mathrm{~m}$ and corresponds to space group number 224. The most intense peak corresponding to the predominant orientation of $\mathrm{Ag}$ nanocrystals is along plane (111), and the Debye-Scherrer equation predicts that the average size of the AgNPs-Sm is around $11 \mathrm{~nm}$, which is consistent with the value obtained by HR-TEM. There is no evidence of other components, such as silver chloride, as possible competitors for the chemical reaction. This indicates again that the reaction is dominated by the synthesis of AgNPs nanocrystals. The FTIR measurement was conducted to identify the possible biomolecules of the $S$. mammosum extract responsible for the reduction and stabilization of AgNPs-Sm. The IR spectra comparison between $\mathrm{AgNO}_{3}$, lyophilized AgNPs-Sm, and S. mammosum dry leaves is shown in Figure $2 \mathrm{~F}$. In the AgNPs-Sm IR spectrum, the band decreases to $3600 \mathrm{~cm}^{-1}$, which corresponds to the $\mathrm{O}-\mathrm{H}$ stretching of alcohols or phenols in relation to the extract, since they could act as reducing agents to synthesize AgNPs. ${ }^{4,72}$ At $1744 \mathrm{~cm}^{-1}$, band of the quinone's $(\mathrm{C}=\mathrm{O})$ functional group could be observed in the spectrum of the plant extract, but it is absent in the AgNPs-Sm spectrum. ${ }^{73}$

\section{Antioxidant Activity by ORAC-FL}

The ORAC-FL kinetic profile at different concentrations is shown in Figure 3A. The area under the fluorescence decay curve (AUC) was calculated by integrating the decrease in fluorescence. The Trolox calibration curve (3 $\mu \mathrm{M}$ a $20 \mu \mathrm{mol} \mathrm{L}-1)$ is shown in Figure 3B. For the aqueous extract of $S$. mammosum leaves, antioxidant activity was determined to be $3944 \pm 112 \mu \mathrm{M} \mathrm{TE} / \mathrm{g}$ of sample. The antioxidant capacity through this methodology is directly related to the reaction's stoichiometry and the low reactivity of the probe used, not to the reactivity of the phenolic compounds present in the extract. ${ }^{74,75}$ The antioxidant activity of the AgNPs-Sm was $637.5 \pm 14.8 \mu \mathrm{M} \mathrm{TE} / \mathrm{g}$ of sample. This decrease is because the antioxidant compounds present in the extract were oxidized in the preparation of the AgNPs and, therefore, no longer had labile hydrogens to react with the peroxyl radical. It should be noted that although the ORAC-FL methodology does not determine the reactivity of antioxidants, the formation of AgNPs could be an indirect measurement of the ability of this type of compound to react and is related to the content of the reducing compounds determined through the FolinCiocalteu methodology. The decrease in antioxidant capacity is consistent with the results of Okiei et al $^{76}$ who measured ascorbic acid as it is related to the amount of vitamin C (antioxidant) in Solanum aethiopicum. Comparing the antioxidant activity of AgNPs using the aqueous extract of Baccharis latifolia ${ }^{85}$ leaves by ORAC$\mathrm{FL}$, the activity decreased in a similar proportion from the extract to the nanoparticle, which corresponded to $87 \%$ versus 84\% for AgNPs-Sm. Regarding the approximate values of antioxidant activity of AgNPs using crop plants, they fall within the range of 3000 to $8000 \mathrm{mg} \mathrm{TE} / \mathrm{mg} \mathrm{mL}$ using the same technique. ${ }^{77}$

\section{Cellular Antioxidant Activity (CAA)}

The CAA kinetic profile of the aqueous extract and AgNPs$\mathrm{Sm}$ is shown in Figure 3C. The 2',7'dichlorodihydrofluorescein diacetate $\left(\mathrm{DCFH}_{2}-\mathrm{DA}\right)$ probe was passively diffused through the cellular membrane and transformed into $\mathrm{DCFH}_{2}$, a nonfluorescent compound that emits fluorescence when oxidized to 2,7-dichlorofluorescein (DFC) by intracellular ROS due to intracellular esterase. The percentage of CAA was determined to be $14.7 \pm 0.2$ for the aqueous extract and $12.5 \pm 0.2$ for the AgNPs-Sm. Both samples were at the same concentrations. The antioxidant activity was lower for AgNPs-Sm, which is consistent with that for ORAC-FL. Moncada-Basualto et al ${ }^{62}$ determined that cellular antioxidant activity has a relationship with lipophilicity (ie, major lipophilicity activity is associated with minor antioxidant activity), possibly due to a better interaction with the cell membrane, which could indicate the low percentages of antioxidant activity of the extracts and AgNPs-Sm, as well as the limited entry of the compounds into the cells, due to the polarity of the aqueous extracts. The main polyphenolic compounds in Solanum are quercetin, gallic acid, and rutin, among others. ${ }^{78,79}$ Wolfe et $\mathrm{al}^{80}$ studied the cellular antioxidant activity of different polyphenolic compounds and determined that quercetin has high CAA compared to gallic acid and rutin. Our data obtained from the CAA for the aqueous extract and the AgNPs-Sm corroborate this finding.

\section{Antioxidant Activity by Differential Pulse Voltammetry (DPV) and Cyclic Voltammetry (CV)}

DPV and CV were used to evaluate the electrochemical behavior of the aqueous extract of S. mammosum leaves. 

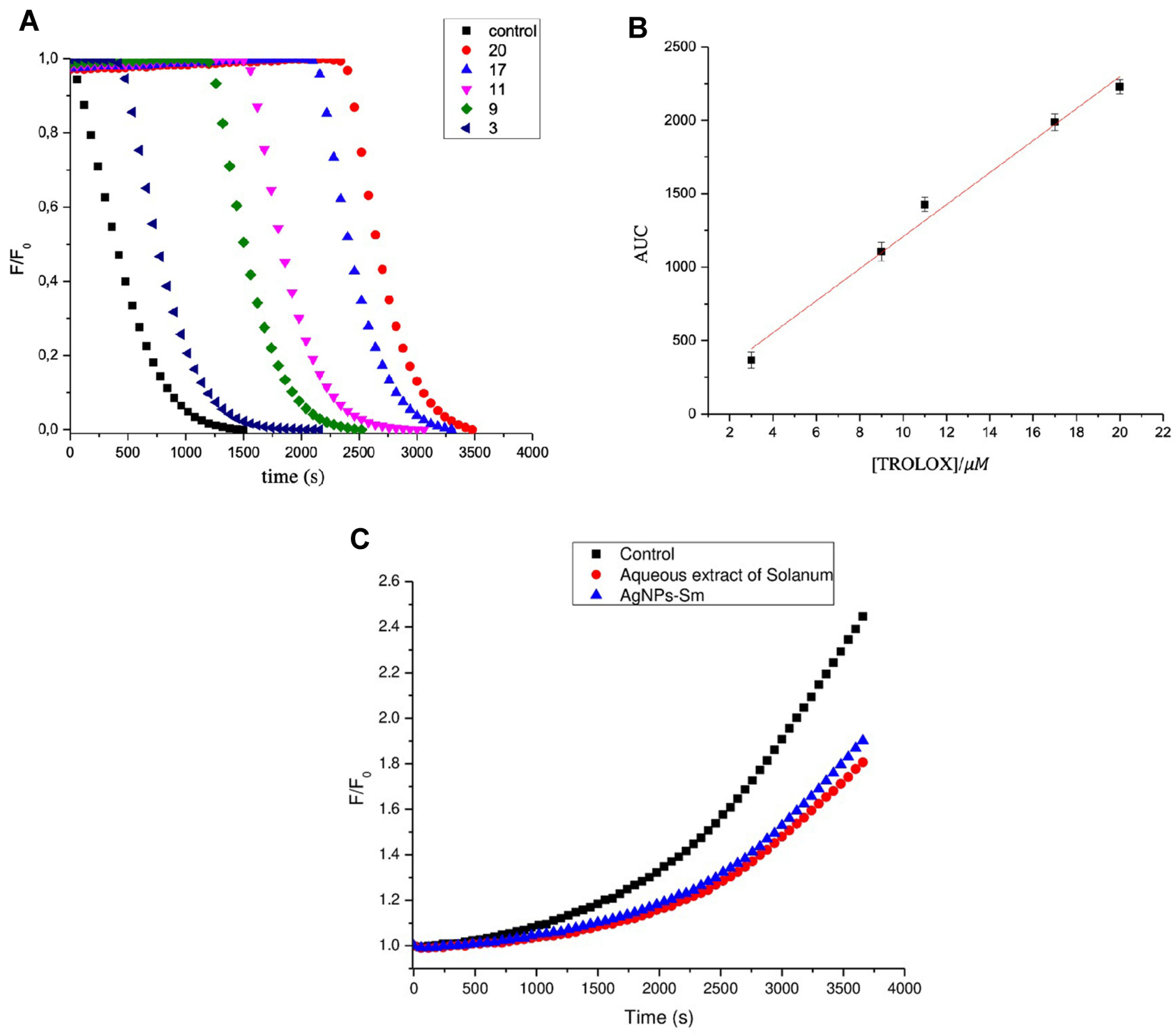

Figure 3 Oxygen radical absorption capacity using fluorescein (ORAC-FL) and cellular antioxidant activity (CAA) analysis. (A) Kinetic profile of ORAC-FL in different concentrations, (B) Trolox calibration curve and (C) kinetic profile of CAA of the aqueous extract and AgNPs-Sm.

In Figure 4, the DPV voltammograms, obtained at different initial scanning potentials using sodium acetate 0.1 mol $\mathrm{L}^{-1}$, are compared (Figure 4A). For the S. mammosum leaf extract, when the voltammogram starts at $+0.5 \mathrm{~V}$ (Figure 4B), two oxidation waves are observed, one at $+0.87 \mathrm{~V}$ and the other at $+1.37 \mathrm{~V}$; when the sweep starts at $+1.2 \mathrm{~V}$, two additional waves appear (Figure 4C) that have a lower current intensity and lower potentials than the aforementioned waves. These results suggest the presence of four types of species with antioxidant capacity in the extract. The voltammogram of the AgNPs-Sm extract started at $-0.5 \mathrm{~V}$ also shows the four voltamperometric waves described for the extract without nanoparticles but with lower current values. Waves at lower oxidation potentials are associated with compounds with a greater capacity to donate electrons and vice versa, and those with higher currents indicate the concentration of antioxidants dissolved in the solution or the number of electrons exchanged per antioxidant. The electrochemical index (EI) was obtained by measuring these parameters using the voltammograms. ${ }^{87}$ The calculated EI was 402 $\mu \mathrm{A} / \mathrm{V}$ for the extract without nanoparticles and $324 \mu \mathrm{A} / \mathrm{V}$ for the AgNPs-Sm, which are values consistent with those obtained for these extracts through the ORAC-FL method; further, the extract with Ag nanoparticles showed lower oxidizing activity and lower content of oxidizing species. 


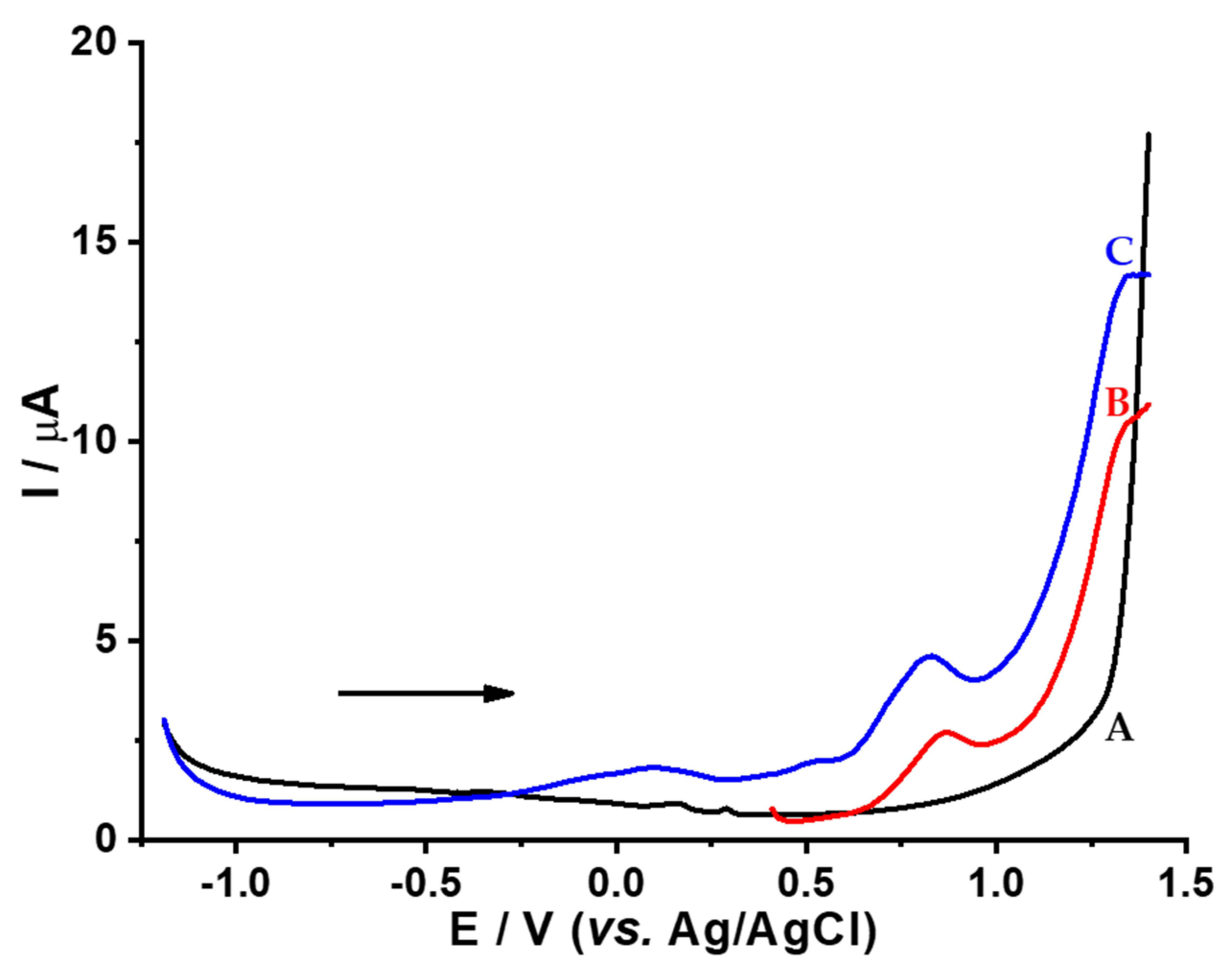

Figure 4 Differential pulse voltammetry analysis of Solanum mammosum extract at GC electrode in $0.10 \mathrm{~mol} \mathrm{~L}^{-1}$. (A) Sodium acetate 0.1 mol $\mathrm{L}^{-1}$, (B) initial potential scan +0.5 $\mathrm{V}$ and (C) initial potential scan $-\mathrm{I} .2 \mathrm{~V}$. Scanning rate $50 \mathrm{mV} \mathrm{s}-\mathrm{I}$ vs $\mathrm{Ag} / \mathrm{AgCl}$ at $25^{\circ} \mathrm{C}$.

To calculate EI, the thermodynamic parameter Epa expresses reducing power, while the kinetic and quantitative parameter Ipa expresses the speed of electron transfer and/or the amount of antioxidant content in the sample. When the EI calculation resulting from the extracts with and without nanoparticles was compared, the Epa remained constant for both extracts, while the Ipa was lower for the extract with nanoparticles. According to these results and considering that "antioxidant activity" refers to the reaction speed between antioxidants and the oxidizable species and "antioxidant capacity" refers to the amount (in moles) of radicals recovered per one mole of antioxidant (that is, the stoichiometric factor), we can conclude that the $S$. mammosum extract has greater antioxidant activity than the extract that contains the nanoparticles; however, both possess antioxidant capacity and therefore the same type of antioxidant species. As the EI provides an effective measure of the antioxidant power (capacity and/or activity) of a given chemical species and is usually correlated with phenolic compounds, the corresponding analysis is presented in the following sections.

Figure 5 shows the CVs of the $S$. mammosum extract in relation to the blank sodium acetate $0.1 \mathrm{~mol} \mathrm{~L}^{-1}$ solution (Figure 5A) starting at potentials of $+0.0 \mathrm{~V}$ (Figure 5C) and sufficiently negative potentials, $-1.5 \mathrm{~V}$ (Figure $5 \mathrm{~B}$ ), to promote electrochemical reduction of dissolved oxygen to radical species such as $\mathrm{HO}_{2}{ }^{\bullet}$ and $\mathrm{HO}^{\bullet} .^{81,82}$ The reducing direction of the voltammogram in Figure $5 \mathrm{C}$ shows a reduction wave to $-0.7 \mathrm{~V}$, which is also present in the voltammogram of the electrolyte medium with no extract, Figure 4A; this reduction wave is associated with the reduction of oxygen. In the oxidation direction, two waves are seen, the first between $+0.2 \mathrm{~V}$ and $0.35 \mathrm{~V}$ and the second to $0.6 \mathrm{~V}$, which, as in the voltammogram obtained by DVP (Figure 5B), are absent in the voltammogram started at $+0.0 \mathrm{~V}$ (Figure $5 \mathrm{C}$ ). This result can be interpreted in the following way: in the voltammogram started at $+1.5 \mathrm{~V}$, the electrochemical reduction of the $\mathrm{O}_{2}$ dissolved in the solution generates reactive radicals that react with the antioxidant species present in the extract, where the product of this reaction can generate other electroactive species that are responsible for the signal obtained in the oxidation sweep between the $+0.2 \mathrm{~V}$ and $0.35 \mathrm{~V}$ potentials. On the other hand, in both the voltammogram initiated at $+0.0 \mathrm{~V}$ and the one initiated at $-1.5 \mathrm{~V}$, the appearance of cathodic signals at the $+0.5 \mathrm{~V}$ potential (Figures 5C), apparently coupled with the anodic processes, in the sweep in the oxidation direction, suggests 


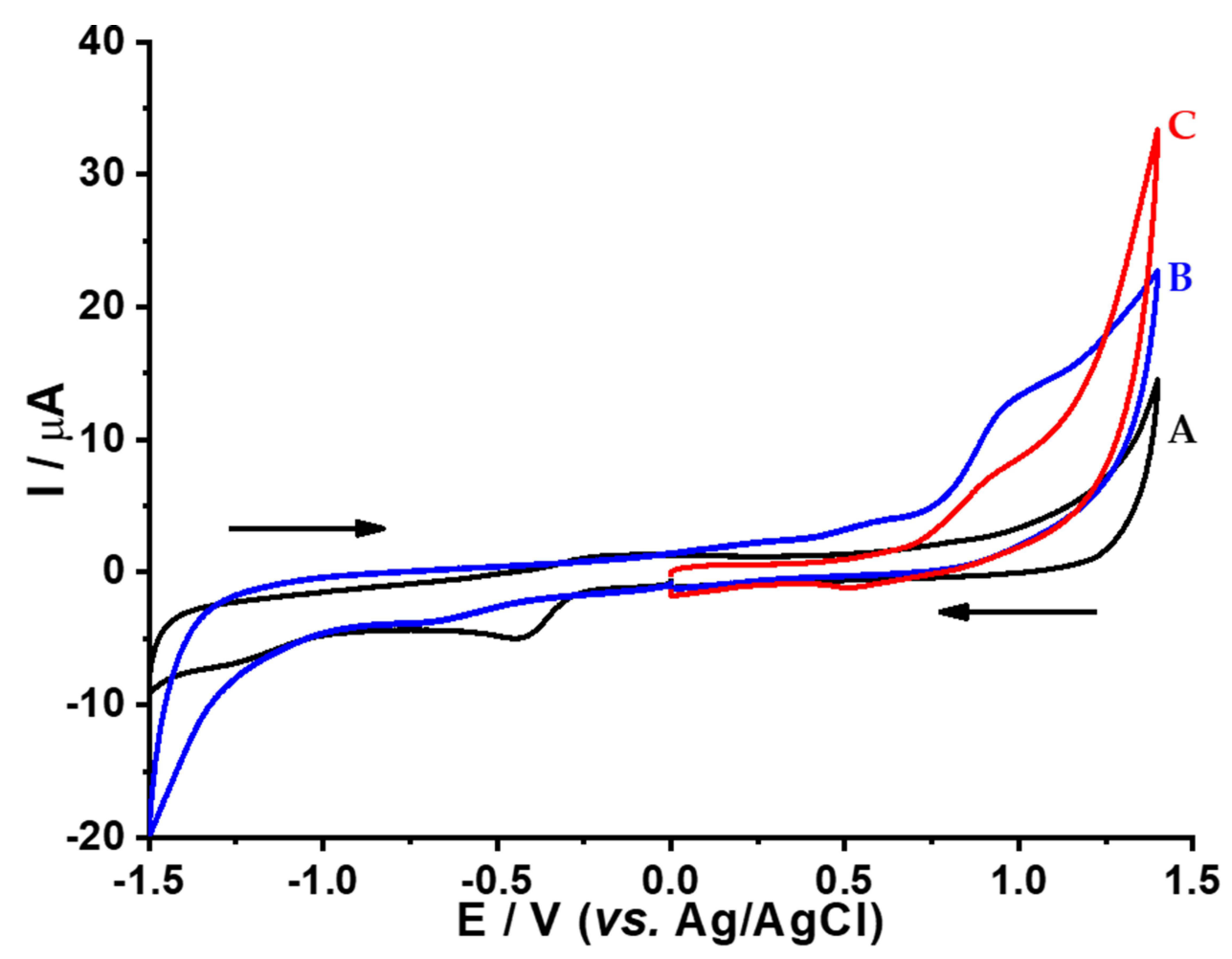

Figure 5 Cyclic voltammograms of Solanum mammosum extract in 0.10 mol L-I sodium acetate solution in 0.10 mol L $\mathrm{L}^{-1}$ at $\mathrm{GC}$ electrode. (A) blank sodium acetate 0.1 mol $\mathrm{L}^{-1}$, (B) initial potential scan $+0.5 \mathrm{~V}$ and $(\mathbf{C})$ initial potential scan $-1.2 \mathrm{~V}$. Scanning rate $50 \mathrm{mV} \mathrm{s}{ }^{-1} \mathrm{vs} \mathrm{Ag} / \mathrm{AgCl}$ at $25^{\circ} \mathrm{C}$.

that the redox processes involved have a certain degree of electrochemical reversibility. These results suggest that in the aqueous extract of $S$. mammosum, additional compounds are generated when electrochemical conditions are present that promote ROS generation, which again corroborates the presence of compounds that are highly reactive with ROS, that is, chemical components with high antioxidant capacity, in this extract.

Several studies have been conducted that use CV to detect antioxidant capacity in species belonging to the Solanaceae family. For example, Domenech-Carbó et al carried out an electrochemical characterization of the fruit of $S$. lycopersicum L. applying $\mathrm{CV}^{83}$ and performed in situ monitoring of the reactivity of this species' phenolic compounds with ROS. ${ }^{84}$

\section{Total Polyphenolic Content (TPH)}

The total polyphenolic content (TPH) of the aqueous extract of S. mammosum and AgNPs-Sm was determined, finding a respective content shown in Table 1 . The difference in the value from de-extract to AgNPs-Sm is due to the decrease in the reducing capacity of the phenolic compounds by the formation of AgNPs, which is lower in their concentration by oxidation and in their antioxidant capacity by the electron transfer mechanism. These results are consistent with those reported by Oszmianski et $\mathrm{al}^{85}$ who characterized the phenolic compounds and antioxidant capacity of the fruits of Solanum scabrum and Solanum burbankii. When comparing the results obtained with AgNPs using different extracts, such as $S$. intermedia for example, the decrease in the total polyphenolic content of the extract to the nanoparticle is considerable, going from $2.398 \pm 0.0028$ to $0.507 \pm 0.0031$ (mg EGA/g of dried plant).

\section{Polyphenolic Profile}

The phenolic compounds' retention times, which have been previously described for the genus Solanum ${ }^{78}$ (Table 2), were determined using the aforementioned elution program as part of a multicomponent analysis. The chromatogram corresponding to the Solanum mammosum extract showed two high-intensity peaks at 2.23 and 17.19 min. However, these peaks could not be attributed to any of the standards used. Only one of the observed peaks was attributable to gallic acid, as shown in Figure 6. The phenolic acid has also been identified in extracts of Solanum lycopersicum L., as well as rutin and quercetin. ${ }^{86}$ The confirmation of the presence of only one of the phenolic compounds used as a standard may be due to the type of extraction performed; 
Table I Total Polyphenolic Content in Solanum Mammosum and AgNPs-Sm

\begin{tabular}{|l|c|}
\hline Sample & $\begin{array}{c}\text { Total Polyphenolic Content (mg EAG/ } \\
\text { I00 g Dry Mass) }\end{array}$ \\
\hline Solanum mammosum & $826.6 \pm 20.9$ \\
AgNPs-Sm & $139.7 \pm 20.9$ \\
\hline
\end{tabular}

Table 2 HPLC Retention Times of Polyphenol Standards

\begin{tabular}{|l|c|}
\hline Compound & Retention Time (min) \\
\hline Gallic acid & 2.90 \\
Catechin & 5.47 \\
Quercetin & 21.29 \\
Resveratrol & 26.03 \\
Kaempferol & 28.80 \\
\hline
\end{tabular}

the extract was aqueous, and gallic acid is highly soluble in water, unlike polyphenolic compounds, whose water solubility is low. Chun Wang et $\mathrm{al}^{78}$ identified the presence of different polyphenols - gallic acid, protocatechuic acid, gallocatechin, caffeic acid, gallocatechin gallate, rutin, quercetin, and naringenin in Solanum nigrum extracts using a different extraction method.

\section{Microbiological Analysis}

A nontoxic effect for the Solanum mammosum extracts, independent of the concentration and the analysis test used, was observed for both strains. An agar dilution test revealed a clear inhibitory effect of $\mathrm{AgNO}_{3}$ (up to 1 microgram of $\mathrm{AgNO}_{3}$ per disc) (Figure 7A) and a very weak growth inhibition of AgNPs-Sm (only with 100 micrograms of AgNPs-Sm) (Figure 7B) for Bacillus sp., likely due to the soluble $\mathrm{Ag}^{+}$present in AgNPs-Sm, as previously described. ${ }^{87}$ Unexpectedly, no inhibitory effect was observed with the agar dilution test $\left(\mathrm{AgNO}_{3}\right.$ and $\left.\mathrm{AgNPs}-\mathrm{Sm}\right)$ for Escherichia coli. Nevertheless, MIC analysis revealed a clear toxic effect for $\mathrm{AgNO}_{3}$ and AgNPs-Sm, though for both strains, the inhibitory effect of AgNPs-Sm was weaker than that for $\mathrm{AgNO}_{3}$. Thus, Bacillus sp. showed a strong inhibitory effect for $\mathrm{AgNO}_{3}$ at $64 \mathrm{mg} / \mathrm{L}$ and a similar response for AgNPs-Sm at $128 \mathrm{mg} / \mathrm{L}$ (Figure 7C). For Escherichia coli (Figure 7D), the strongest inhibitory effect

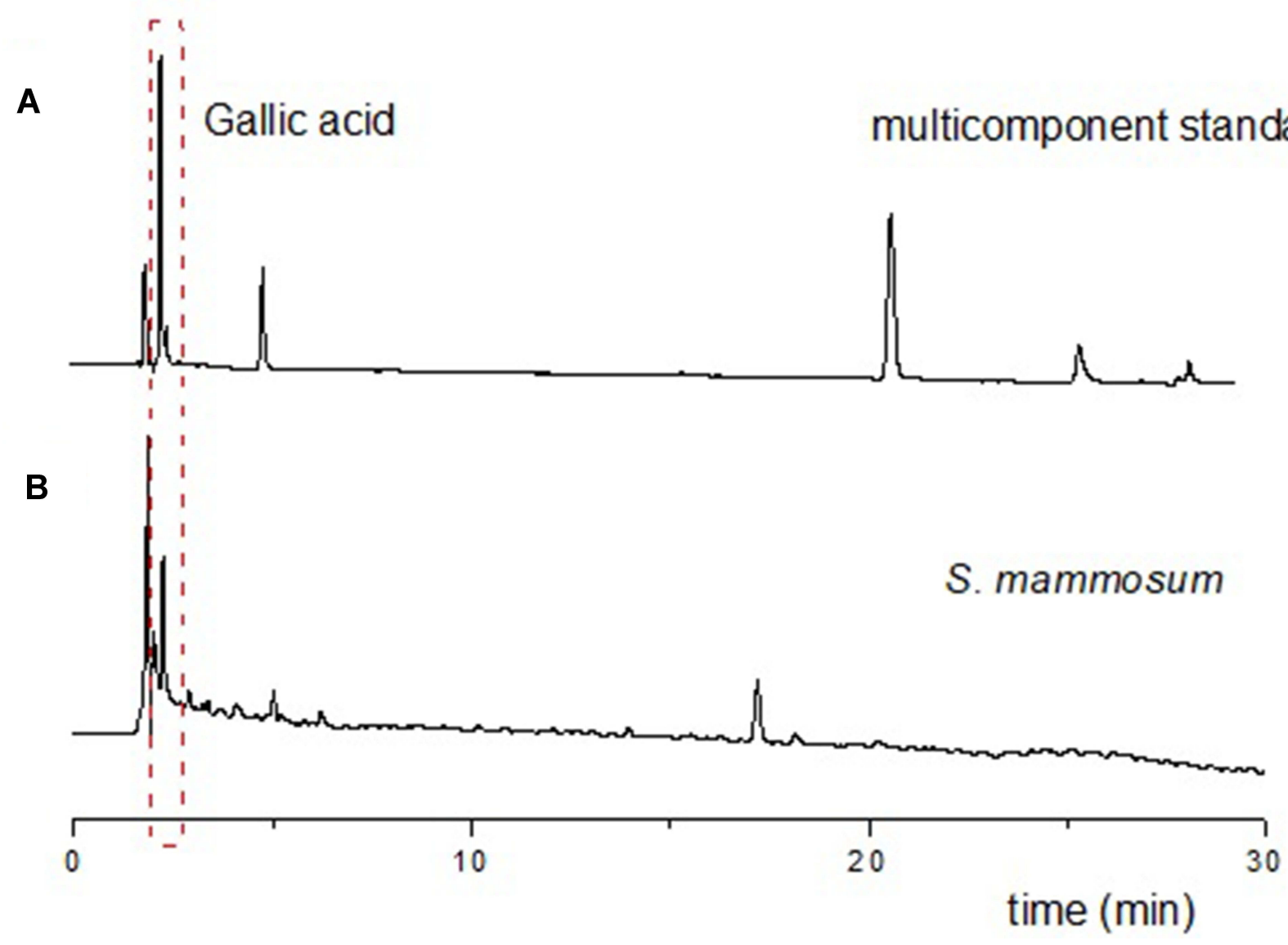

Figure 6 Antioxidant analysis. HPLC-MS chromatogram with (A) multicomponent standards and (B) S. mammosum extract. 

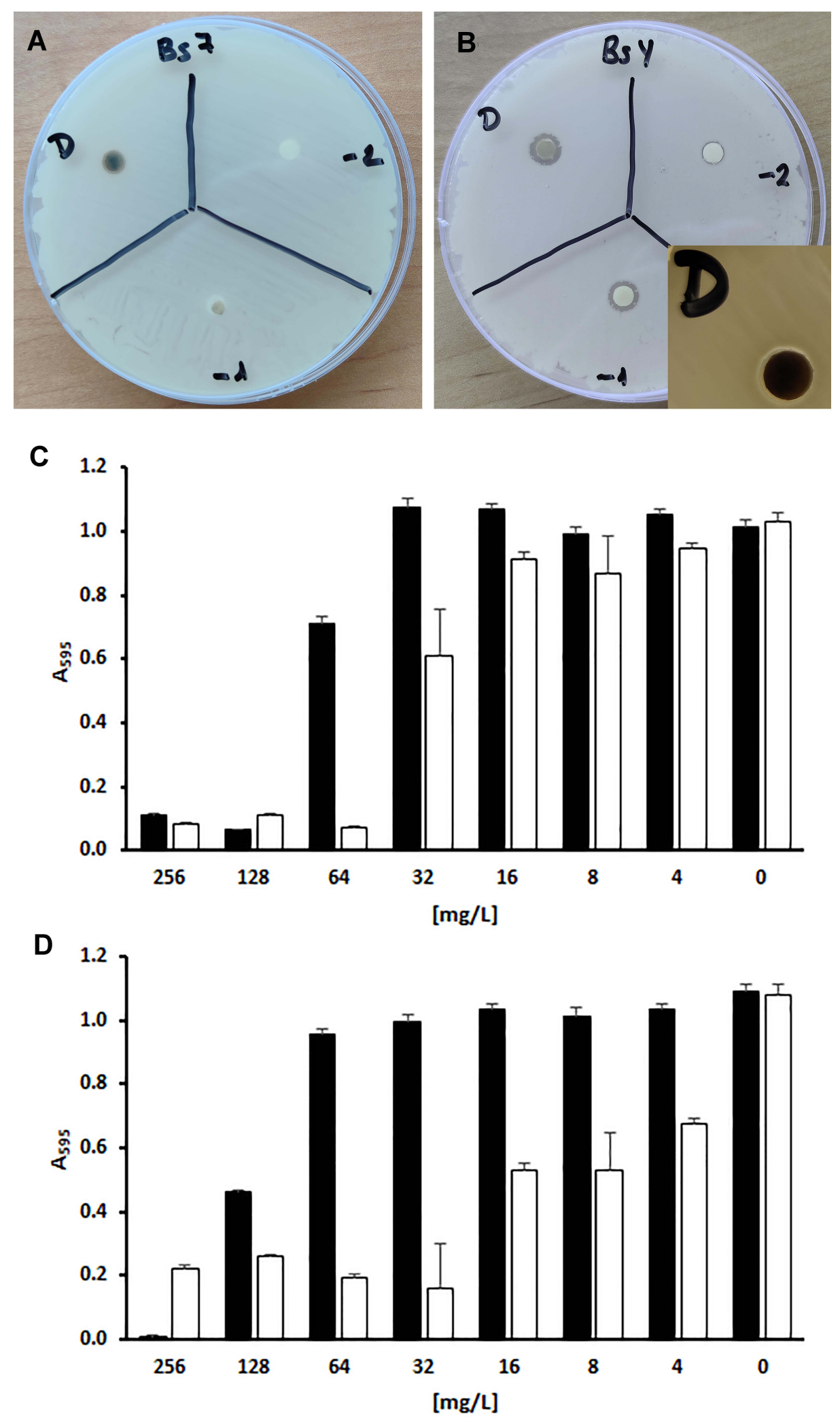

Figure 7 Microbial susceptibility tests. Panels (A and B) agar diffusion tests of Bacillus sp. (A) CECT 40 to AgNO3 and (B) AgNPs-Sm; quantities load on the discs were 100 micrograms (discs labelled as (D), 10 micrograms ( -1 ) and I micrograms ( -2 ). Panels (C and D) MICs for Bacillus sp. CECT 40 (C) and Escherichia coli CECT I0I (D) using $\mathrm{AgNO}_{3}$ (white) and AgNPs-Sm (black); values are average and SD. 
started at $32 \mathrm{mg} / \mathrm{L}$ for $\mathrm{AgNO}_{3}$, although the measured optical density values suggest that a higher fraction of Escherichia coli cells were alive when compared to the Bacillus sp.affected cultures (average of 0.2 and 0.1 absorbance units for Bacillus sp. and Escherichia coli, respectively) (Figure 7C and D). This difference might explain the lack of an inhibition zone for Escherichia coli in the agar dilution tests. Finally, although the inhibitory effect of AgNPs-Sm for Escherichia coli started at $128 \mathrm{mg} / \mathrm{L}$, a concentration of $256 \mathrm{mg} / \mathrm{L}$ was needed to observe an inhibitory effect similar (higher) to that observed for $\mathrm{AgNO}_{3}$ (Figure 7C). Thus, it was clear that the inhibitory effect of AgNPs-Sm was higher for Bacillus sp. than for Escherichia coli, as described in the previous literature, ${ }^{88}$ and was weaker for both strains than that detected for $\mathrm{AgNO}_{3}$.

\section{Conclusions}

The current study demonstrated the antioxidant activity of the aqueous extract of $S$. mammosum when obtaining AgNPs-Sm measuring $5.2 \pm 2.3 \mathrm{~nm}$. The values of the extract's antioxidant capacity analyzed by different techniques (ORAC-FL, CAA, DPV, CV, and TPH) decrease in relation to AgNPs, which could be an indirect measure of the ability of polyphenolic compounds such as gallic acid to react with the reducing compounds present. Likewise, it was determined that the extracts and nanoparticles generated antioxidant activity at the cellular level. Microbiological analysis revealed that the Solanum mammosum extract was nontoxic for Bacillus sp. and Escherichia coli. A weak growth inhibitory effect was observed for the AgNPs-Sm for both bacterial strains in the presence of $\mathrm{Ag}^{0}$ nanoparticles. The use of AgNPs to determine the antioxidant capacity of new molecules from plant extracts can be potentially applicable in biomedicine.

\section{Abbreviations}

AgNPs, silver nanoparticles; Sm, Solanum mammosum L.; SPR, surface plasmon resonance; ROS, reactive oxygen species; RNS, reactive nitrogen species; BHT, butylated hydroxytoluene; BHA, butylated hydroxyanisole; ORAC-FL, oxygen radical absorbance capacity using fluorescein; CAA, cellular antioxidant activity; $\mathrm{CV}$, cyclic voltammetry; DPV, differential pulse voltammetry; HPLC, high-performance liquid chromatography; DAD, diode array detector; HR-TEM, high-resolution transmission electron microscope; DLS, dynamic light scattering meter; XRD, X-ray diffraction; FTIR-ATR, attenuated total reflection Fourier-transform infrared spectroscopy;
GC, glassy carbon electrode; SAED, selected area electron diffraction; ET, expressed as Trolox; EAG, expressed as gallic acid.

\section{Acknowledgments}

This research was funded by the Pontificia Universidad Católica del Ecuador www.puce.edu.ec.

Thanks to Dr. Mónica Jadán (ESPE) and MSc. Omar Vacas (Herbarium PUCE-Quito) for plant collection.

\section{Authors' Contributions}

All authors made a significant contribution to the work reported, whether that is in the conception, study design, execution, acquisition of data, analysis and interpretation, or in all these areas; took part in drafting, revising or critically reviewing the article; gave final approval of the version to be published; have agreed on the journal to which the article has been submitted; and agree to be accountable for all aspects of the work.

\section{Funding}

This research was funded by the Pontificia Universidad Católica del Ecuador www.puce.edu.ec.

\section{Disclosure}

The author reports no conflicts of interest in this work.

\section{References}

1. Kumar B, Smita K, Debut A, Cumbal L. Extracellular green synthesis of silver nanoparticles using Amazonian fruit araza (Eugenia stipitata McVaugh). Trans Nonferrous Met Soc China. 2016;26(9):2363-2371. doi:10.1016/S1003-6326(16)64359-5

2. Vizuete KS, Kumar B, Vaca AV, Debut A, Cumbal L. Mortiño (Vaccinium floribundum Kunth) berry assisted green synthesis and photocatalytic performance of silver-graphene nanocomposite. J Photochem Photobiol a Chem. 2016;329:273-279. doi:10.1016/j. jphotochem.2016.06.030

3. Morejón B, Pilaquinga F, Domenech F, Ganchala D, Debut A, Neira M. Larvicidal activity of silver nanoparticles synthesized using extracts of Ambrosia arborescens (Asteraceae) to control Aedes aegypti L. (Diptera: Culicidae). J Nanotechnol. 2018;2018:1-8. doi: $10.1155 / 2018 / 6917938$

4. Echavarría ZB, Franco SA, Martínez MA. Evaluación de la actividad antioxidante y determinación del contenido de compuestos fenólicos en extractos de macroalgas del Caribe Colombiano. Vitae. 2020;16 (1):126-131.

5. Abdelghany TM, Al-Rajhi AMH, Al Abboud MA, et al. Recent advances in green synthesis of silver nanoparticles and their applications: about future directions. A review. Bionanoscience. 2018;8 (1):5-16. doi:10.1007/s12668-017-0413-3

6. Ahmed S, Ahmad M, Swami BL, Ikram S. A review on plants extract mediated synthesis of silver nanoparticles for antimicrobial applications: a green expertise. $J A d v$ Res. 2016;7(1):17-28. doi:10.1016/j. jare.2015.02.007 
7. Robles A, Fabjanowicz M, Chmiel T, Płotka-Wasylka J. Determination and identification of organic acids in wine samples. Problems and challenges. Trends Anaytl Chem. 2019;120:115630. doi:10.1016/j.trac.2019.115630

8. Park JW, Park KG, Lee NY, Lee JH, Lee JW. Enhanced extraction of reducing sugars from fruit of Hovenia dulcis with treatment of cellulase and sequential production of ethanol and acetic acid containing ampelopsin from extracted reducing sugars. Ind Crops Prod. 2019;139:111522. doi:10.1016/j.indcrop.2019.111522

9. Michna A, Morga M, Adamczyk Z, Kubiak K. Monolayers of silver nanoparticles obtained by green synthesis on macrocation modified substrates. Mater Chem Phys. 2019;227:224-235. doi:10.1016/j. matchemphys.2019.01.072

10. Mittal AK, Chisti Y, Banerjee UC. Synthesis of metallic nanoparticles using plant extracts. Biotechnol Adv. 2013;31(2):346-356. doi:10.1016/j.biotechadv.2013.01.003

11. Tauanov Z, Tsakiridis PE, Mikhalovsky SV, Inglezakis VJ. Synthetic coal fly ash-derived zeolites doped with silver nanoparticles for mercury (II) removal from water. J Environ Manage. 2018;224 (4):164-171. doi:10.1016/j.jenvman.2018.07.049

12. Jini D, Sharmila S. Green synthesis of silver nanoparticles from Allium cepa and its in vitro antidiabetic activity. Mater Today Proc. 2020;22:432-438. doi:10.1016/j.matpr.2019.07.672

13. Jemilugba OT, Sakho EHM, Parani S, Mavumengwana V, Oluwafemi OS. Green synthesis of silver nanoparticles using Combretum erythrophyllum leaves and its antibacterial activities. Colloid Interface Sci Commun. 2019;31:100191. doi:10.1016/j. colcom.2019.100191

14. Debela S, Mesfin B, Senbeta T. Surface plasmon resonances in ellipsoidal bimetallic nanoparticles. Photonics Nanostructr. 2019;33:48-54. doi:10.1016/j.photonics.2018.11.007

15. Yaremchuk I, Fitio V, Petrovska H, Bobitski Y. The temperature impact on the characteristics of the surface plasmon resonance sensors element. Optik. 2019;192:162969. doi:10.1016/j. ijleo.2019.162969.

16. Zhou J, Qi Q, Wang C, et al. Surface plasmon resonance (SPR) biosensors for food allergen detection in food matrices. Biosens Bioelectron. 2019;142:111449. doi:10.1016/j.bios.2019.111449

17. Valgimigli L, Baschieri A, Amorati R. Antioxidant activity of nanomaterials. $J$ Mater Chem B. 2018;6(14):2036-2051. doi: $10.1039 / \mathrm{c} 8 \mathrm{tb} 00107 \mathrm{c}$

18. Mateus PG, Wolf VG, Borges MS, Ximenes VF. Quercetin: prooxidant effect and apoptosis in cancer. In: Atta-ur-Rahman, editor. Studies in Natural Products Chemistry. Vol. 58. Elsevier B. V.;2018:265-288. doi:10.1016/B978-0-444-64056-7.00009-X

19. Suzuki N, Koussevitzky S, Mittler R, Miller G. ROS and redox signalling in the response of plants to abiotic stress. Plant Cell Environ. 2012;35(2):259-270. doi:10.1111/j.1365-3040.2011.02336.x

20. Calle A, San Martin Á, Melgarejo M, Flores Y, Almanza GR. Evaluation of flavonoid contents and antibacterial activity of five Bolivian Baccharis species. Rev Boliv Química. 2017;34(4):112-122.

21. Tripathi D, Modi A, Narayan G, Rai SP. Green and cost effective synthesis of silver nanoparticles from endangered medicinal plant withania coagulans and their potential biomedical properties. Mater Sci Eng C. 2019;100:152-164. doi:10.1016/j.msec.2019.02.113

22. Baranowski ES, Barrett TG, Parsons L. Metabolic syndrome: unravelling or unravelled? Paediatr Child Heal. 2019;29(7):297-302. doi:10.1016/j.paed.2019.04.003

23. Thirunavukkarasu GK, Nirmal GR, Lee H, Lee M, Park I, Lee JY. On-demand generation of heat and free radicals for dual cancer therapy using thermal initiator- and gold nanorod-embedded PLGA nanocomplexes. J Ind Eng Chem. 2019;69:405-413. doi:10.1016/j. jiec.2018.09.051

24. Zandalinas SI, Mittler R. ROS-induced ROS release in plant and animal cells. Free Radic Biol Med. 2018;122:21-27. doi:10.1016/j. freeradbiomed.2017.11.028
25. Palmeira CM, Teodoro JS, Amorim JA, Steegborn C, Sinclair DA, Rolo AP. Mitohormesis and metabolic health: the interplay between ROS, cAMP and sirtuins. Free Radic Biol Med. 2019;141:483-491. doi:10.1016/j.freeradbiomed.2019.07.017

26. Yahia Y, Bagues M, Zaghdoud C, Al-Amri SM, Nagaz K, Guerfel M. Phenolic profile, antioxidant capacity and antimicrobial activity of Calligonum arich L., desert endemic plant in Tunisia. South African $J$ Bot. 2019;124:414-419. doi:10.1016/j.sajb.2019.06.005

27. Jiménez-Zamora A, Delgado-Andrade C, Rufián-Henares JA. Antioxidant capacity, total phenols and color profile during the storage of selected plants used for infusion. Food Chem. 2016;199:339-346. doi:10.1016/j.foodchem.2015.12.019

28. Barroso MF, Ramalhosa MJ, Alves RC, et al. Total antioxidant capacity of plant infusions: assessment using electrochemical DNA-based biosensor and spectrophotometric methods. Food Control. 2016;68:153-161. doi:10.1016/j.foodcont.2016.03.029

29. David M, Serban A, Radulescu C, Danet AF, Florescu M. Bioelectrochemical evaluation of plant extracts and gold nanozyme-based sensors for total antioxidant capacity determination. Bioelectrochemistry. 2019;129:124-134. doi:10.1016/ j.bioelechem.2019.05.011

30. Giaquinta Aranda A, Fernández Araque A, Curbelo Rodriguez R, Rojo Aragues A. Glaucoma y antioxidantes: revisión sistemática. Rev Mex Oftalmol. 2017;91(3):112-121. doi:10.1016/j.mexoft.2016.03.007

31. Martínez-Rojano H, Sámano R, Tolentino M, Morales Hernández RM, Ramírez C, Pizano Zárate ML. Utilidad de un método que determina simultáneamente retinol y $\alpha$-tocoferol en leche materna por cromatografía líquida de alta resolución. Perinatol Reprod Hum. 2016;30(4):151-158. doi:10.1016/j.rprh.2016.11.009

32. Restrepo G, Montoya JD, Rojano B. Capacidad antioxidante y calidad post-descongelación de semen equino criopreservado con quercetina y ergotioneina. Rev Med Vet Zoot. 2016;63(3):167-178. doi:10.15446/rfmvz.v63n3.62747

33. Zakharova OD, Frolova TS, Yushkova YV, et al. Antioxidant and antitumor activity of trolox, trolox succinate, and $\alpha$-tocopheryl succinate conjugates with nitroxides. Eur $J$ Med Chem. 2016;122:127-137. doi:10.1016/j.ejmech.2016.05.051

34. Wang W, Kannan P, Xue J, Kannan K. Synthetic phenolic antioxidants, including butylated hydroxytoluene (BHT), in resin-based dental sealants. Environ Res. 2016;151:339-343. doi:10.1016/j. envres.2016.07.042

35. Fernández-álvarez L, Del Valle P, de Arriaga D, García-Armesto MR, Rúa J. Binary combinations of BHA and other natural and synthetic phenolics: antimicrobial activity against Staphylococcus aureus and antioxidant capacity. Food Control. 2014;42:303-309. doi:10.1016/j. foodcont.2014.02.020

36. Laghrib F, Houcini H, Khalil F, et al. Synthesis of silver nanoparticles using chitosan as stabilizer agent: application towards electrocatalytical reduction of p-nitrophenol. ChemistrySelect. 2020;5 (3):1220-1227. doi:10.1002/slct.201903955

37. Nasirizadeh N, Shekari Z, Dehghani M. ScienceDirect delphinidin immobilized on silver nanoparticles for the simultaneous determination of ascorbic acid, noradrenalin, uric acid, and tryptophan. $J$ Food Drug Anal. 2016;24(2):406-416. doi:10.1016/j.jfda.2015.11.011

38. Lattanzio V. Phenolic compounds: introduction. In: Ramawat KG, Mérillon JM, editors. Natural Products: Phytochemistry, Botany and Metabolism of Alkaloids, Phenolics and Terpenes. Berlin Heidelberg: Springer-Verlag; 2013:1543-1580. doi:10.1007/978-3-642-22144-6

39. Lim TK. Solanum mammosum. In: Edible Medicinal and NonMedicinal Plants. Vol. 6. Springer;2013:364-369. doi:10.1007/97894-017-7276-1

40. Vega Orcacitas M. Etnobotánica de La Amazonía Peruana. 1st ed. Abya-Yala; 2001.

41. Wetwitayaklung P, Phaechamud T, June A. Antioxidant activities and phenolic content of Solanum and Capsicum sp. Res J Pharm Biol Chem Sci. 2011;2(2):146-154. 
42. Kuo KW, Hsu SH, Li YP, et al. Anticancer activity evaluation of the Solanum glycoalkaloid solamargine: triggering apoptosis in human hepatoma cells. Biochem Pharmacol. 2000;60(12):1865-1873. doi:10.1016/S0006-2952(00)00506-2

43. Wong CC, Wang Y, Cheng KW, Chiu JF, He QY, Chen F. Comparative proteomic analysis of indioside D-triggered cell death in HeLa cells. J Proteome Res. 2008;7(5):2050-2058. doi:10.1021/pr800019k

44. Muñoz V, Sauvain M, Bourdy G, et al. The search for natural bioactive compounds through a multidisciplinary approach in Bolivia. Part II. Antimalarial activity of some plants used by mosetene Indians. J Ethnopharmacol. 2000;69(2):139-155. doi:10.1016/ S0378-8741(99)00096-3

45. Alzérreca A, Hart G. Molluscicidal steroid glycoalkaloids possessing stereoisomeric spirosolane structures. Toxicol Lett. 1982;12(23):151-155. doi:10.1016/0378-4274(82)90178-3

46. Nava-Pérez E, García-Gutiérrez C, Camacho-Báez JR, VázquezMontoya EL. Bioplaguicidas: una opción para el control biológico de plagas biopesticides: an option for the biological pest control. $R a$ Ximhai. 2012;8(3):17-29. doi:10.35197/rx.08.03.e2.2012.03.en

47. Quijano M, Riera-Ruíz C, Barragán A, Miranda M, Orellana T, Manzano P. Molluscicidal activity of the aqueous extracts from Solanum mammosum L., Sapindus saponaria L. and Jatropha curcas L. against Pomacea canaliculata. Emirates J Food Agric. 2014;26 (10):871-877. doi:10.9755/ejfa.v26i10.18804

48. Alfonso MM, Avilés R, Alvarez ME, et al. Molusquicidas naturales de origen botánico. Rev Agrotec Cuba. 2005;1-15.

49. Rojas S, de Los MA. Uso de extractos vegetales de plantas amazónicas para el diseño de programas de manejo integrado de plagas (MIP) en Ecuador; 2018.

50. Ortega I, Cuba C, Castellanos L, Martín C, Cuba C. Inventario de plantas repelentes y/o fitoplaguicidas en las unidades de la agricultura urbana de la provincia de Cienfuegos. Rev Cent Agric. 2008;35(1):91-93.

51. Veitía Rubio MM Curso-taller nacional "Manejo Agroecológico de Plagas en la Agricultura Suburbana". Programa de Agricultura Urbana y Suburbana. MINAGRI; 2010:1-12.

52. Kvist LP, Alarcón D. Plantas Tóxicas. In: Enciclopedia de Las Plantas Útiles Del Ecuador. Herbario QCA de la Escuela de Ciencias Biológicas de la Pontificia Universidad Católica del Ecuador \& Herbario AAU del Departamento de Ciencias Biológicas de la Universidad de Aarhus; 2008:99-104.

53. Syahrani A, Indrayanto G, Wilkins A. Bioconversion of salicylamide by cell suspension cultures of Solanum mammosum. Chem Pharm Bull. 1997;45(3):555-557. doi:10.1248/cpb.45.555

54. Syahrani A, Indrayanto G, Wilkins A, Sutarjadi S. Glucosylation of salicyl alcohol by cell suspension cultures of Solanum mammosum. Nat Prod Sci. 1997;3(1):71-74.

55. Syahrani A, Ratnasari E, Indrayanto G, Wilkins AL. Biotransformation of o- and p-aminobenzoic acids and $\mathrm{N}$-acetyl paminobenzoic acid by cell suspension cultures of Solanum mammosum. Phytochemistry. 1999;51(5):615-620. doi:10.1016/ S0031-9422(99)00112-0

56. Indrayanto G, Margalin H, Ratnasari E, Syahrani A. Densitometric determination of O-aminobenzoic acid, $\beta$-D-glucopyranosyl1-O-aminobenzoate, and O- $\beta$-D-glucopyranosyl- $(1 \rightarrow \quad 6)-\mathrm{O}-\beta$ D-glucopyranosyl-1-O-aminobenzoate in cell-suspension cultures of Solanum mammosum. J Planar Chromatogr. 1999;12(6):456-460.

57. Hartanti L, Widjaja I, Syahrani A, Indrayanto G. High yield formation of O-aminobenzoic acid-7-O- $\beta$-D- $(\beta-1, \quad 6-O-D-g l u c o p y r a n o s y l)-$ glucopyranosyl ester in cell suspension cultures of Solanum mammosum. J Asian Nat Prod Res. 2002;4(1):61-65. doi:10.1080/ 10286020290019712

58. Indrayanto G, Sondakh R, Syahrani A, Utami W. Solanum mammosum L. (Terong Susu): in vitro culture and the production of steroidal alkaloids and other secondary metabolites. In: Bajaj YPS, editor. Biotechnology in Agriculture and Forestry; 1998:394-414. doi:10.1007/978-3-642-58833-4_20
59. Pilaquinga F, Morejón B, Ganchala D, et al. Green synthesis of silver nanoparticles using Solanum mammosum L. (Solanaceae) fruit extract and their larvicidal activity against Aedes aegypti L. (Diptera: Culicidae). PLoS One. 2019;14(10):1-13. doi:10.1371/ journal.pone.0224109

60. Amaguaña Pacheco DI Síntesis y caracterización de nanopartículas de plata usando como reductor químico el extracto acuoso de las hojas de sensitiva (Mimosa albida); 2018.

61. Matos MJ, Pérez-Cruz F, Vazquez-Rodriguez S, et al. Remarkable antioxidant properties of a series of hydroxy-3-arylcoumarins. Bioorg Med Chem. 2013;21(13):3900-3906. doi:10.1016/j.bmc.2013.04.015

62. Moncada-Basualto M, Lapier M, Maya JD, et al. Evaluation of trypanocidal and antioxidant activities of a selected series of 3-amidocoumarins. Med Chem. 2018;14(6):573-584. doi:10.2174/ 1573406414666180419113437

63. Pérez-Cruz K, Moncada-Basualto M, Morales-Valenzuela J, et al. Synthesis and antioxidant study of new polyphenolic hybrid-coumarins. Arab J Chem. 2018;11(4):525-537. doi:10.1016/ j.arabjc.2017.05.007

64. Robledo-O'Ryan N, Moncada-Basualto M, Mura F, et al. Synthesis, antioxidant and antichagasic properties of a selected series of hydroxy-3-arylcoumarins. Bioorg Med Chem. 2017;25(2):621-632. doi:10.1016/j.bmc.2016.11.033

65. Leal D, Mansilla A, Matsuhiro B, et al. Chemical structure and biological properties of sulfated fucan from the sequential extraction of subAntarctic Lessonia sp (Phaeophyceae). Carbohydr Polym. 2018;199:304-313. doi:10.1016/j.carbpol.2018.07.012

66. Pilaquinga F, Amaguaña D, Morey J, et al. Synthesis of silver nanoparticles using aqueous leaf extract of Mimosa albida (Mimosoideae): characterization and antioxidant activity. Materials. 2020;13(3):503. doi:10.3390/ma13030503

67. Folin O, Ciocalteau V. Tyrosine and Tryptophane in Proteins. J Biol Chem. 1927;73(2):627-648. doi:10.1016/S0021-9258(18)84277-6

68. Weinstein MP, Patel JB, Burnhman C-A, Zimmer BL. Clinical and laboratory standards institute methods for dilution antimicrobial susceptibility tests for bacteria that grow aerobically standard, approval CDM-A. In: M07 Methods Dilution Antimicrob Susceptibility Tests Bact That Grow Aerob. 2018:91.

69. Pradeep T. A Textbook of Nanoscience and Nanotechnology. Tata McGraw-Hill Education; 2012.

70. Ramesh S, Grijalva M, Debut A, de la Torre BG, Albericio F, Cumbal LH. Peptides conjugated to silver nanoparticles in biomedicine - a "value-added" phenomenon. Biomater Sci. 2016;4 (12):1713-1725. doi:10.1039/c6bm00688d

71. Das RK, Bhuyan D. Microwave-mediated green synthesis of gold and silver nanoparticles from fruit peel aqueous extract of Solanum melongena L. and study of antimicrobial property of silver nanoparticles. Nanotechnol Environ Eng. 2019;4(1):1-6. doi:10.1007/s41204-0180052-0

72. Gorbe M, Bhat R, Aznar E, et al. Rapid biosynthesis of silver nanoparticles using pepino (Solanum muricatum) leaf extract and their cytotoxicity on HeLa cells. Materials. 2016;9(5):325.

73. Chattopadhyay S, Sarkar P, Chudhury UR. Estimation of tea polyphenols by differential pulse voltammetry with electrodes modified by tyrosinase extracted from crude sources. J Electrochem Soc. 2015;162(4):B101-B108. doi:10.1149/2.0991504jes

74. Dorta E, Fuentes-Lemus E, Aspée A, et al. The ORAC (oxygen radical absorbance capacity) index does not reflect the capacity of antioxidants to trap peroxyl radicals. $R S C$ Adv. 2015;5 (50):39899-39902. doi:10.1039/c5ra01645b

75. Dorta E, Aspée A, Pino E, González L, Lissi E, López-Alarcón C. Controversial alkoxyl and peroxyl radical scavenging activity of the tryptophan metabolite 3-hydroxy-anthranilic acid. Biomed Pharmacother. 2017;90:332-338. doi:10.1016/j.biopha.20 17.03 .082 
76. Okiei W, Ogunlesi M, Adeyemi A, Obakachi V, Ikhile M, Nkenchor G. The voltammetric and titrimetric determination of ascorbic acid levels in tropical fruit samples. Int J Electrochem Sci. 2009;4:276-287.

77. Bello-Bello JJ, Chavez-Santoscoy RA, Lecona-Guzmán CA, et al. Hormetic response by silver nanoparticles on in vitro multiplication of sugarcane (Saccharum spp. Cv. Mex 69-290) using a temporary immersion system. Dose-Response. 2017;15(4):1-9. doi:10.1177/ 1559325817744945

78. Wang H-C, Chung P-J, Wu C-H, Lan K-P, Yang M-Y, Wang C-J. Solanum nigrum L. polyphenolic extract inhibits hepatocarcinoma cell growth by inducing $\mathrm{G} 2 / \mathrm{M}$ phase arrest and apoptosis. $J \mathrm{Sci}$ Food Agric. 2011;91(1):178-185. doi:10.1002/jsfa.4170

79. Boix YF, Torres JM, Chavez ER, et al. Evaluacion cualitativa de monoterpenos en Rosmarinus officinalis cultivados con agua tratada magneticamente/Qualitative evaluation of monoterpenes in Rosmarinus officinalis cultivated with magnetically treatment water. Cultiv Trop. 2016;37(1):136. doi:10.13140/RG.2.1.3710.4246

80. Wolfe KL, Liu RH. Cellular antioxidant activity (CAA) assay for assessing antioxidants, foods, and dietary supplements. J Agric Food Chem . 2007;55(22):8896-8907. doi:10.1021/jf0715166

81. Marselli B, Garcia-Gomez J, Michaud PA, Rodrigo MA, Comninellis C. Electrogeneration of hydroxyl radicals on boron-doped diamond electrodes. J Electrochem Soc. 2003;150(3): D79. doi:10.1149/1.1553790

82. Kapałka A, Fóti G, Comninellis C. The importance of electrode material in environmental electrochemistry. Formation and reactivity of free hydroxyl radicals on boron-doped diamond electrodes. Electrochim Acta. 2009;54(7):2018-2023. doi:10.1016/j.electacta.20 08.06 .045
83. Doménech-Carbó A, Domínguez I, Hernández-Muñoz P, Gavara R. Electrochemical tomato (Solanum lycopersicum L.) characterisation using contact probe in situ voltammetry. Food Chem. 2015;172:318-325. doi:10.1016/j.foodchem.2014.09.066

84. Doménech-Carbó A, Gavara R, Hernández-Muñoz P, Domínguez I. Contact probe voltammetry for in situ monitoring of the reactivity of phenolic tomato (Solanum lycopersicum L.) compounds with ROS. Talanta. 2015;144:1207-1215.

85. Oszmiański J, Kolniak-Ostek J, Wojdyło A. Characterization of phenolic compounds and antioxidant activity of Solanum scabrum and Solanum burbankii berries. J Agric Food Chem. 2014;62 (7):1512-1519. doi:10.1021/jf4045233

86. Dubois AEF, Boix YF, Luna LMG, Cuypers A. Polyphenol content in Solanum lycopersicum under the action of a static magnetic field. Cultiv Trop. 2016;37:142-147. doi:10.13140/RG.2.1.3448.2808

87. Hsueh YH, Lin KS, Ke WJ, et al. The antimicrobial properties of silver nanoparticles in bacillus subtilis are mediated by released Ag+ ions. PLoS One. 2015;10(12):1-17. doi:10.1371/journal. pone. 0144306

88. Doody MA, Wang D, Bais HP, Jin Y. Differential antimicrobial activity of silver nanoparticles to bacteria Bacillus subtilis and Escherichia coli, and toxicity to crop plant Zea mays and beneficial B. subtilis-inoculated Z. mays. J Nanoparticle Res. 2016;18(10). doi:10.1007/s11051-016-3602-z
International Journal of Nanomedicine

\section{Publish your work in this journal}

The International Journal of Nanomedicine is an international, peerreviewed journal focusing on the application of nanotechnology in diagnostics, therapeutics, and drug delivery systems throughout the biomedical field. This journal is indexed on PubMed Central, MedLine, CAS, SciSearch ${ }^{\mathbb{}}$, Current Contents ${ }^{\mathbb{R}} /$ Clinical Medicine, $^{2}$

\section{Dovepress}

Journal Citation Reports/Science Edition, EMBase, Scopus and the Elsevier Bibliographic databases. The manuscript management system is completely online and includes a very quick and fair peer-review system, which is all easy to use. Visit http://www.dovepress.com/ testimonials.php to read real quotes from published authors. 